\title{
Widening mortality disparities by educational attainment among native-born Americans adults over 3 decades of follow up: the mystery deepens
}

\author{
Tal Gross ${ }^{1}$, Sherry Glied ${ }^{2}$, Peter Muennig*1 \\ ${ }^{1}$ Mailman School of Public Health, Columbia University, New York, United States \\ ${ }^{2}$ Wagner School, New York University, New York, United States
}

Received: July 11, 2015

DOI: $10.5430 /$ ijh.v1n1p40

\author{
Accepted: July 30, 2015 \\ Online Published: August 14, 2015 \\ URL: http://dx.doi.org/10.5430/ijh.v1n1p40
}

\begin{abstract}
Mortality disparities between high school dropouts and high school graduates may be widening over time. These changes could simply reflect demographic changes among dropouts over time or could represent changes to the cognitive or social benefits of education itself. We used a unique dataset that contains 32 years of survey data, 38 years of mortality follow-up data, and a wide array of psychological, sociological, cognitive, and demographic questions to explore the underlying causes of widening disparities in survival among high school dropouts relative to graduates. We focus on individuals surveyed from 1978 through 1997, and focus on ten-year survival for each respondent. We confirm that mortality disparities between high school dropouts and high school graduates have widened over time. We also find that the racial composition, parental education, racial mix of neighborhoods, income, and verbal IQ of high school dropouts and high school graduates have changed greatly over the past three decades. However, while each of these factors is itself an important determinant of survival, we find that none of these factors (or combinations of them) explain the widening mortality disparities by high school graduation status over the two time periods we study. The widening disparities in survival time by educational attainment we observe are not linked to changes in the socio-demographic characteristics of high school dropouts relative to high school graduates.
\end{abstract}

Key Words: Health disparities, Social inequality, Morbidity and mortality, Epidemiology

\section{BACKGROUND}

Mortality disparities between high school dropouts and graduates have increased over the past four decades in the United States, and female high school dropouts have actually experienced a deterioration in life expectancy over time. ${ }^{[1-7]}$ A decline in life expectancy for a group of this size is unprecedented within a nation that is not undergoing disease epidemics, natural disasters, or political collapse. ${ }^{[8,9]}$ Over the same period, more-educated Americans of both sexes saw gains in life expectancy, leading to a growing gap in survival between the less and more educated. ${ }^{[10]}$ There are a number of competing or overlapping explanations for this phenomenon:

First, poverty is a powerful predictor of both dropping out of high school and of poor health and longevity. ${ }^{[11,12]}$ Therefore, these growing mortality disparities among high school graduates and dropouts might simply reflect changes in individual socio-demographic characteristics. For example,

${ }^{*}$ Correspondence: Peter Muennig; Email: pm124@columbia.edu; Address: MSPH Box 14, 600 West 168th Street, 6th Floor, New York, NY 10032, United States. 
it could be increasing numbers of poor children who both have poor health and poor high school graduation rates that explain why education disparities are widening over time. This is possible because more children are born into such families over time. ${ }^{[13]}$ If poverty is the underlying cause of widening disparities, then high school dropouts and graduates may be different from one another before they ever set foot in a grade-school classroom. Such a finding might not set off alarm bells within education policy because it is the students that require attention (whether in the form of early family interventions, redistribution programs, or means tested education programs) rather than the schools themselves.

Second, while poverty is a powerful predictor of future educational attainment and future health, cognitive ability is also an independent predictor of a child's chances of graduating from high school and his or her chances of being healthy. ${ }^{[14]}$ School quality is a potentially powerful determinant of a child's cognitive ability. Therefore, school quality could also explain the growing mortality disparities by educational attainment.

Third, a diploma seems to be an increasingly important determinant of one's future earnings and employment, two other factors that are very important correlates of health and longevity. ${ }^{[11]}$ As the wages of high school dropouts and graduates have diverged, graduates may have enjoyed increasing access to health-enhancing goods and services, such as safe neighborhoods or better food, over time. ${ }^{[11,15]}$ Consistent with this hypothesis, prior research suggests that adult unemployment contributes to the growing gap in mortality by educational attainment. ${ }^{[16]}$

Finally, high school education could improve people's life satisfaction, which might indirectly contribute to health outcomes. The theory is that less satisfied and less happy people have more stress (or more stressed people are less satisfied and less happy) and that this stress leads to harmful physiological changes and behavioral risk factors such as smoking. Consistent with this hypothesis, prior research suggests that smoking contributes to the growing gap in mortality by educational attainment. ${ }^{[16]}$

Much of the prior work examining the underlying causes of increasing mortality disparities by educational attainment has been conducted by Jennifer Karas-Montez along with various other researchers. ${ }^{[16-20]}$ These studies tend to explore the underlying contributors to these disparities using an intuitive, but fixed methodology and set of theoretical assumptions. They find that smoking and unemployment are explanatory factors, however the effects were far too small to support either the life satisfaction or the macroeconomic hypotheses mentioned above. Moreover, smoking rates have not changed much between high school graduates and dropouts in recent times in the general population.

\section{METHODS}

\subsection{Overview}

In this paper, we first describe changes in the socioeconomic and demographic characteristics of high school dropouts among respondents to a very detailed national survey, comparing those who responded between 1978 and 1987 and those who responded between 1988 and 1997. For a given explanation to be valid, it must: (1) have changed over time, and (2) have contributed to the growing mortality disparities by educational attainment. We selected explanatory factors a priori by categorizing the variables at our disposal into those that would identify: (1) sociological characteristics, (2) demographic characteristics, (3) psychological characteristics, and (4) cognitive skills. These variables are listed in Table 1.

We test these variables or groups of variables in two ways. First, we explored whether the variables have changed over time. Second, we tested whether they might have explained the growing mortality disparities by educational attainment over time, measured as 10-year survival.

\subsection{Study population}

We used data from the 1978-2002 General Social Surveys (GSS) linked to the National Death Index (NDI) through 2008 (2008 GSS-NDI). ${ }^{[21]}$ Each wave is based on a newly drawn, nationally representative population sample. In the 2008 GSS-NDI, survey respondents from 18 waves of the GSS were prospectively linked to mortality data by cause of death. The data were successfully merged and validated without issue. Surveys are administered face-to-face. Details of this public use dataset are available elsewhere, including nonresponse rates by survey year, corrections for non-response bias. ${ }^{[21]}$ Extensive documentation surrounding the sampling frame and quality control measures are documented on the General Social Survey website. The GSS-NDI project was directed by one of the authors (PM) and institutional review board approval was obtained from the Columbia University Medical Center.

The 2008 GSS-NDI contains 32,830 GSS participants. We restrict the sample to respondents who are at least 25 years old at the time of survey, are not foreign born, and do not have graduate degrees. Using the 25 and over sample aggregated by gender, we then divided the sample into two periods: 1978 through 1987 and 1988 through 1997, which we refer to as "the early period" and "the late period", respectively. We chose these periods because they allowed for the estimation of 10-year survival for each surveyed individual in our 
sample (i.e., those surveyed in 1997 were observed in 2008). Those restrictions leave us with 8,751 respondents surveyed in the early period, and 9,796 respondents surveyed in the late period.

\subsection{Approach}

An argument can be made for running the analyses guided by previous work in this area, including those for whom the gradient may be widening to the greatest extent (e.g., women and those aged 45-65). ${ }^{[20]}$ While this allows for a focus on the groups that might be most impacted, our sample and periods differed significantly from these earlier analyses. We nevertheless ran separate analyses that only included participants in periods for which educational disparities were increasing in one study as previously recommended. We also ran analyses separately by gender because women seem to be predominantly impacted in many studies. These supplemental analyses are available from the authors, but they both reduce our statistical power and, rather than increasing the coefficient size, do not impact our coefficients greatly.

Table 1. Summary statistics (number of respondents, percentage [\%] or mean value by study period and dropout status, 2008 General Social Survey-National Death Index)

\begin{tabular}{|c|c|c|c|c|}
\hline & & riod & & Period \\
\hline & Dropout & Graduate & Dropout & Graduate \\
\hline$N$ & 2,681 & 6,070 & 1,999 & 7,797 \\
\hline Female & 0.60 & 0.58 & 0.60 & 0.58 \\
\hline Age at survey & 56.04 & 43.58 & 58.48 & 46.11 \\
\hline Black & 0.23 & 0.13 & 0.19 & 0.12 \\
\hline Other Race & 0.02 & 0.01 & 0.04 & 0.02 \\
\hline Mother a high school dropout & 0.71 & 0.42 & 0.66 & 0.34 \\
\hline Household finances satisfactory & 0.30 & 0.28 & 0.27 & 0.28 \\
\hline Happy with life & 0.83 & 0.90 & 0.84 & 0.90 \\
\hline Mixed-race neighborhood & 0.47 & 0.50 & 0.53 & 0.60 \\
\hline Income greater than $\$ 50,000$ & 0.18 & 0.39 & 0.22 & 0.45 \\
\hline Homeowner & 0.65 & 0.68 & 0.61 & 0.69 \\
\hline Verbal IQ & 4.53 & 6.31 & 4.44 & 6.29 \\
\hline Lives in a high-crime neighborhood & 0.48 & 0.41 & 0.49 & 0.42 \\
\hline Spends time with parents & 0.25 & 0.45 & 0.24 & 0.43 \\
\hline
\end{tabular}

Note. The data consist of the 1978 through 2002 General Social Survey linked to 2008 National Death Index mortality data. Sample is unweighted.

While prior studies have used sophisticated models to examine whether specific variables contribute to the widening gap in educational attainment over time, ${ }^{[19,20]}$ we exploit the fact that the 2008 GSS-NDI was conducted over a long time period and that it contains an unusually rich set of variables. ${ }^{[22]}$ This allows us to utilize a much simpler, more transparent, and more descriptive approach to assessing the growing mortality disparities than by attempting to interact terms in a multi-year, multiple cross sectional dataset with hugely differential follow up times and widely different potential for causes of death. For example, a 25-year-old surveyed in 1985 would be exposed to a much broader array of causes of death through 2008 than would a 65-year old surveyed in 2002.

We test whether the variables in the GSS-NDI explain the growing gap in mortality with Cox proportionate hazards models. We then add control variables to the models to ascertain whether they might explain changes between the late and early periods. We test whether the mortality gap between dropouts and graduates has grown significantly over time, and whether that growing gap can be explained by including the covariates available in the GSS, using an interacted Cox hazards model. We report results of $p$-tests for the equivalence of dropout effects over the two time periods.

In particular, we begin with a standard hazards model:

$$
\begin{aligned}
& \lambda\left(t \mid X_{i}\right)=\lambda_{0}(t) \cdot \\
& \exp \left(\beta_{1} \cdot \text { High School } \text { Dropout }_{i}+\beta_{2} W_{i}\right)
\end{aligned}
$$

Here we model the effect of being a high school dropout on mortality as shifting the hazard of dying over time, $t$. We estimate this model separately for the early period and late period. We then add control variables, $W$, to test whether those control variables affect the high-school-dropout effect in each period.

The sample in each period is a nationally representative sam- 
ple of the US population. Since the age distribution of the US changes over time, we age-adjusted within each period. This way, the sampling frames and follow-up differ only with respect to period.

In the interacted model, we combine both period samples and include an interaction between the period effect and each of the other variables. This specification allows the effect of each variable to be different in the earlier and later period. We test for the difference between the early and later period dropout coefficients.

Standard procedures for analyzing GSS data were followed, and none of the analyses were weighted. We explored relevant interactions that may have influenced comparisons between period 1 and period 2, and controlled for study year within each interval of interest.

\subsubsection{Variables}

We selected variables that were known to be associated with mortality a priori. Not all of these variables were included in all years of the GSS-NDI. We incorporated into our analysis only variables that were present in at least some of the earlier years and at least some of the later years. Nonetheless, variables that were excluded some years were not cleanly distributed across both periods and including such variables produced significant impacts on our sample size. As a result, we divided the variables we felt to be relevant into two categories. One category (the baseline analysis) consisted of influential variables for which there were few missing values. The other category (the sensitivity analysis) included variables that were missing in many sample years. This way, we were able to get a sense of the influence of variables within the sensitivity analysis on the overall inter-period differences in health disparities by educational attainment without compromising the integrity of the baseline analysis.

The baseline and sensitivity analysis variables come from two groups. The first group consists of pre-educational characteristics of the GSS respondents: race (black, white, other) and mother's education (by highest degree obtained). The second group consists of post-educational characteristics: home ownership (yes/no), ${ }^{[23]}$ verbal IQ (which may also be a pre-educational measure and was constructed using the wordsum measure) ${ }^{[24]}$ residence in a high-crime neighborhood (perceived neighborhood safety at night), life satisfaction (based on a 3-item Likert scale), ${ }^{[25]}$ satisfaction with household finances (based on a 3-item Likert scale), living in a mixed-race neighborhood (yes/no), income (in constant 2,000 US dollars) ${ }^{[26]}$ and the frequency with which the respondent spends time with parents (number of visits per year). ${ }^{[27]}$ Each of these characteristics has been associated with changes in survival (see citations).

Published by Sciedu Press

\subsubsection{Analyses}

We estimated Cox proportional hazards models to account for censoring in the observation of death after survey. Our primary outcome measure is mortality among native-born participants age 25 and over. The age restrictions allow us to focus on those causes of death associated with educational attainment that occur in middle-ages (leaving aside, for example, violence, where rates varied between the earlier and later periods) and because education is usually completed by age $25 .^{[28]}$ We tested to ensure that the proportionality assumption was met. In all regressions, we control for age at the time of survey and year of survey.

We ran proportional hazards regressions on two samples: respondents surveyed in 1978-1987 and respondents surveyed in 1988-1997. The key coefficient of interest is the difference in the hazards of dying within 10 years for a high school dropout relative to a graduate in each period. We gradually added demographic controls to the models to assess how those controls mediated the measured disparities in each period. We conducted all analyses using Stata version 11.2.

\section{Results}

Table 1 presents descriptive statistics for the analytic sample. The lot of both high school dropouts and high school graduates tended to generally show a trend toward improvements in risk factors for lower survival time. However, across some categories, the rate of improvement was greater for high school graduates than for high school dropouts. For instance, participants who dropped out of high school and whose mother was a high school dropout fell from $71 \%$ in the early period to $66 \%$ in the late period. Among participants who graduated from high school, the percentages were $42 \%$ and $34 \%$ respectively - a similar but somewhat steeper decline than for dropouts. Most notably, relative to the early period, survey participants who dropped out of high school showed a trend toward a lower likelihood of home ownership, while home ownership was stable among high school graduates.

Table 2 presents estimates of the association between health risk factors and the hazards of dying after the survey in each period. The table presents four models with increasing number of controls, to help the reader subjectively assess how each additional control affects the observed association between high school dropout status and the hazards of death. All models all include controls for age at the time of survey and year of survey.

The first two columns of Table 2 suggest a small association between high school dropout status and mortality hazards in the early period (hazard ratio $[\mathrm{HR}]=1.16 ; 95 \%$ confidence 
interval: $1.08,1.23)$. By contrast, in the late period, we observe that high school dropouts exhibited a $33 \%$ increase in the hazards of death compared to graduates $(\mathrm{HR}=1.33$;
$95 \% \mathrm{CI}=1.23,1.45)$. The difference in the dropout effects across the two periods was statistically significant $(p<.01)$.

Table 2. Cox proportional hazards models predicting all-cause mortality risk, 2008 General Social Survey-National Death Index (Reference group)

\begin{tabular}{|c|c|c|c|c|c|c|c|c|}
\hline \multirow{2}{*}{ Time Period } & \multicolumn{2}{|c|}{ Model 1, HR (95\% CI) } & \multicolumn{2}{|c|}{ Model 2, HR (95\% CI) } & \multicolumn{2}{|c|}{ Model 3, HR (95\% CI) } & \multicolumn{2}{|c|}{ Model 4, HR (95\% CI) } \\
\hline & Early & Late & Early & Late & Early & Late & Early & Late \\
\hline \multirow[t]{2}{*}{$\begin{array}{l}\text { High school dropout (high } \\
\text { school graduates) }\end{array}$} & $1.16^{* * * *}$ & $1.33^{* * *}$ & $1.11^{* *}$ & $1.28^{* * *}$ & $1.11^{* *}$ & $1.29^{* * *}$ & $1.08^{*}$ & $1.25^{* * *}$ \\
\hline & {$[1.08,1.23]$} & {$[1.23,1.45]$} & {$[1.04,1.19]$} & {$[1.18,1.39]$} & {$[1.03,1.19]$} & {$[1.19,1.41]$} & {$[1.01,1.16]$} & {$[1.14,1.36]$} \\
\hline \multirow[t]{2}{*}{ Female (male) } & & & $0.72^{* * *}$ & $0.74^{* * *}$ & $0.72^{* * *}$ & $0.74^{* * *}$ & $0.72^{* * *}$ & $0.74^{* * *}$ \\
\hline & & & {$[0.68,0.77]$} & {$[0.69,0.79]$} & {$[0.68,0.77]$} & {$[0.69,0.79]$} & {$[0.67,0.76]$} & {$[0.68,0.80]$} \\
\hline \multirow[t]{2}{*}{ Black (white) } & & & $1.32^{* * *}$ & $1.39^{* * *}$ & $1.32^{* * *}$ & $1.40^{* * *}$ & $1.32^{* * *}$ & $1.35^{* * *}$ \\
\hline & & & {$[1.21,1.44]$} & {$[1.24,1.55]$} & {$[1.21,1.44]$} & {$[1.25,1.56]$} & {$[1.20,1.44]$} & {$[1.20,1.52]$} \\
\hline \multirow[t]{2}{*}{ Other Race (white) } & & & 1.14 & 0.99 & 1.14 & 1 & 1.14 & 0.92 \\
\hline & & & {$[0.87,1.49]$} & {$[0.73,1.35]$} & {$[0.87,1.49]$} & {$[0.73,1.36]$} & {$[0.86,1.50]$} & {$[0.68,1.26]$} \\
\hline \multirow{3}{*}{$\begin{array}{l}\text { Mother a High School } \\
\text { Dropout (mother a high } \\
\text { school graduate) }\end{array}$} & & & & & & & & \\
\hline & & & & & 1.03 & 0.96 & 1.03 & 0.94 \\
\hline & & & & & {$[0.96,1.09]$} & {$[0.89,1.03]$} & {$[0.96,1.10]$} & {$[0.87,1.01]$} \\
\hline \multirow[t]{2}{*}{$\begin{array}{l}\text { Household finances } \\
\text { satisfactory (household } \\
\text { finances unsatisfactory) }\end{array}$} & & & & & & & 1.01 & 0.97 \\
\hline & & & & & & & {$[0.94,1.08]$} & {$[0.89,1.05]$} \\
\hline \multirow[t]{2}{*}{$\begin{array}{l}\text { Happy with life (unhappy } \\
\text { with life) }\end{array}$} & & & & & & & 0.98 & $0.82^{* * *}$ \\
\hline & & & & & & & {$[0.89,1.08]$} & {$[0.73,0.92]$} \\
\hline \multirow[t]{2}{*}{$\begin{array}{l}\text { Mixed-race neighborhood } \\
\text { (single-race neighborhood) }\end{array}$} & & & & & & & 1.03 & 0.96 \\
\hline & & & & & & & {$[0.96,1.10]$} & {$[0.89,1.04]$} \\
\hline \multirow[t]{2}{*}{$\begin{array}{l}\text { Income greater than } \\
\$ 50,000 \text { (income less than } \\
\$ 50,000 \text { ) }\end{array}$} & & & & & & & $0.89^{* *}$ & $0.87^{* * *}$ \\
\hline & & & & & & & {$[0.83,0.96]$} & {$[0.80,0.94]$} \\
\hline$N$ & 9,504 & 10,989 & 9,504 & 10,989 & 9,504 & 10,989 & 9,065 & 10,301 \\
\hline $\begin{array}{l}p \text {-value testing equal } \\
\text { dropout effects }\end{array}$ & .008 & & .010 & & .006 & & .017 & \\
\hline
\end{tabular}

Models 2 through 4 exhibit a similar pattern: a small association between dropout status and mortality hazards in the early period, and a larger, statistically significant disparity in the late period. The disparity is still statistically significant in the late period and of similar magnitude. This is true even once we control for race, the respondent's mother's high school dropout status, satisfaction with his household's finances, self-reported happiness, living in a mixed-race neighborhood, and earning more than $\$ 50,000$. For instance, in Model 4 , which controls for all of the factors above, high school dropouts exhibited an $8 \%$ increased hazards of premature death in the early period $(\mathrm{HR}=1.08 ; 95 \% \mathrm{CI}=1.01-1.16)$ but a $24 \%$ times greater hazards of dying $(\mathrm{HR}=1.25 ; 95 \%$ $\mathrm{CI}=1.14-1.36)$ in the late period. This is roughly the same difference observed in the model with limited control variables. As with the basic model, the change in the dropout differential between the earlier and later periods remains borderline significant in the more comprehensive model $(p<$ .05 , data not shown).

Table 3 explores the sensitivity of our main results to additional controls. These are variables that would have influenced the power of the study were they included in the main analysis presented in Table 2. Given the number of missing observations for each variable, each model in Table 3 only includes one of these additional controls at a time. All models, however, include controls for gender, race, age at survey, and year of survey. 
Table 3, as a whole, suggests that these additional controls (homeownership, verbal IQ, living in a high-crime neighborhood, spending time with parents, ever smoked, and ever unemployed) do not change the basic patterns seen in Table 2. For instance, Model 1 suggests hazards in the early period $(\mathrm{HR}=1.11 ; 95 \% \mathrm{CI}=1.04,1.19)$ and in the late period (HR $=1.28 ; 95 \% \mathrm{CI}=1.18,1.39)$ that are comparable to those seen in model 5 (early $\mathrm{HR}=1.09 ; 95 \% \mathrm{CI}=1.00,1.19$ and late $\mathrm{HR}=1.25 ; 95 \% \mathrm{CI}=1.11,1.41)$. Home ownership, verbal IQ, and smoking are statistically significant predictors of mortality in the late period, but do not appear to explain much of the observed changes in mortality disparities by diploma status.

Table 3. Cox proportional hazards models predicting all-cause mortality risk, 2008 General Social Survey-National Death Index (Reference group)

\begin{tabular}{|c|c|c|c|c|c|c|c|c|c|c|c|c|c|c|}
\hline \multirow{2}{*}{ Time Period } & \multicolumn{2}{|c|}{$\begin{array}{l}\text { Model 1, HR } \\
(95 \% \text { CI })\end{array}$} & \multicolumn{2}{|c|}{$\begin{array}{l}\text { Model 2, HR } \\
(95 \% \mathrm{CI})\end{array}$} & \multicolumn{2}{|c|}{$\begin{array}{l}\text { Model 3, HR } \\
(95 \% \text { CI })\end{array}$} & \multicolumn{2}{|c|}{$\begin{array}{l}\text { Model 4, HR } \\
(95 \% \text { CI })\end{array}$} & \multicolumn{2}{|c|}{$\begin{array}{l}\text { Model 5, HR } \\
(95 \% \text { CI) }\end{array}$} & \multicolumn{2}{|c|}{$\begin{array}{l}\text { Model 6, HR } \\
(95 \% \mathrm{CI})\end{array}$} & \multicolumn{2}{|c|}{$\begin{array}{l}\text { Model 7, HR } \\
(95 \% \text { CI })\end{array}$} \\
\hline & Early & Late & Early & Late & Early & Late & Early & Late & Early & Late & Early & Late & Early & Late \\
\hline \multirow[t]{2}{*}{$\begin{array}{l}\text { High School Dropout (high } \\
\text { school graduate) }\end{array}$} & $1.11^{* *}$ & $\begin{array}{l}1.28 \\
* * *\end{array}$ & $1.14^{*}$ & $\begin{array}{l}1.25 \\
* * *\end{array}$ & 1.11 & $\begin{array}{l}1.17 \\
* *\end{array}$ & $1.12^{* *}$ & $\begin{array}{l}1.31 \\
* * *\end{array}$ & $1.09^{*}$ & $\begin{array}{l}1.25 \\
* * *\end{array}$ & $1.11^{*}$ & $\begin{array}{l}1.20 \\
* *\end{array}$ & $1.10^{*}$ & $\begin{array}{l}1.28 \\
* * *\end{array}$ \\
\hline & $\begin{array}{l}{[1.04,} \\
1.19]\end{array}$ & $\begin{array}{l}{[1.18,1} \\
.39]\end{array}$ & $\begin{array}{l}{[1.02,} \\
1.28]\end{array}$ & $\begin{array}{l}{[1.12} \\
1.38]\end{array}$ & $\begin{array}{l}{[0.99} \\
1.23]\end{array}$ & $\begin{array}{l}{[1.05} \\
1.32]\end{array}$ & $\begin{array}{l}{[1.03,} \\
1.22]\end{array}$ & $\begin{array}{l}{[1.18,} \\
1.46]\end{array}$ & $\begin{array}{l}{[1.00} \\
1.19]\end{array}$ & $\begin{array}{l}{[1.11} \\
1.41]\end{array}$ & $\begin{array}{l}{[1.02,} \\
1.20]\end{array}$ & $\begin{array}{l}{[1.07,} \\
1.36]\end{array}$ & $\begin{array}{l}{[1.01} \\
1.20]\end{array}$ & $\begin{array}{l}{[1.15,} \\
1.41]\end{array}$ \\
\hline \multirow[t]{2}{*}{ Home Owner (renter) } & & & 0.92 & $\begin{array}{l}0.75 \\
* * *\end{array}$ & & & & & & & & & & \\
\hline & & & $\begin{array}{l}{[0.82} \\
1.04]\end{array}$ & $\begin{array}{l}{[0.68} \\
0.83]\end{array}$ & & & & & & & & & & \\
\hline \multirow[t]{2}{*}{ Verbal IQ (continuous) } & & & & & 0.99 & $\begin{array}{l}0.96 \\
* *\end{array}$ & & & & & & & & \\
\hline & & & & & $\begin{array}{l}{[0.97} \\
1.02]\end{array}$ & $\begin{array}{l}{[0.94,} \\
0.99]\end{array}$ & & & & & & & & \\
\hline \multirow[t]{2}{*}{$\begin{array}{l}\text { Lives in a high-crime } \\
\text { neighborhood (lives in a } \\
\text { low-crime neighborhood) }\end{array}$} & & & & & & & 1.03 & 1.07 & & & & & & \\
\hline & & & & & & & $\begin{array}{l}{[0.94,} \\
1.12]\end{array}$ & $\begin{array}{l}{[0.97} \\
1.18]\end{array}$ & & & & & & \\
\hline \multirow[t]{2}{*}{$\begin{array}{l}\text { Spends time with parents } \\
\text { (spends no time with parents) }\end{array}$} & & & & & & & & & 0.95 & 1 & & & & \\
\hline & & & & & & & & & $\begin{array}{l}{[0.86} \\
1.04]\end{array}$ & $\begin{array}{l}{[0.87} \\
1.16]\end{array}$ & & & & \\
\hline \multirow[t]{2}{*}{ Smokes (not a smoker) } & & & & & & & & & & & ${ }_{* * *}^{1.19}$ & ${ }_{* * *}^{1.29}$ & & \\
\hline & & & & & & & & & & & $\begin{array}{l}{[1.10} \\
1.29]\end{array}$ & $\begin{array}{l}{[1.15,} \\
1.45]\end{array}$ & & \\
\hline \multirow[t]{2}{*}{$\begin{array}{l}\text { Ever employed (never } \\
\text { employed) }\end{array}$} & & & & & & & & & & & & & 1.08 & 1.12 \\
\hline & & & & & & & & & & & & & $\begin{array}{l}{[0.97,} \\
1.19]\end{array}$ & $\begin{array}{l}{[0.99,} \\
1.26]\end{array}$ \\
\hline$N$ & 9,504 & 10,989 & 3,708 & 7,149 & 4,853 & 6,946 & 6,056 & 7,206 & 5,930 & 4,503 & 6,925 & 4,509 & 5,498 & 7,331 \\
\hline $\begin{array}{l}p \text {-value testing equal dropout } \\
\text { effects }\end{array}$ & .010 & & .261 & & .451 & & .023 & & .073 & & .235 & & .031 & \\
\hline
\end{tabular}

\section{Discussion}

We test whether growing survival time disparities in the United States between high school dropouts and high school graduates can be explained by the changing sociological, demographic, psychological, behavioral risk factor, or cognitive characteristics of less-educated groups. Our results suggest that mortality disparities by educational attainment have indeed grown, and that the characteristics of high school dropouts have changed somewhat over time. For example, in recent years, high school dropouts are somewhat more likely to be African American and to have parents who themselves were high school dropouts. With the exception of home ownership however, both groups trended toward improvements in known risk factors for decreased survival time, ${ }^{[29]}$ just at slightly different rates.

Our analyses do not suggest that such socio-demographic changes account for the growing gap in mortality hazards between those with more and less educational attainment. Specifically, factors such as verbal IQ, income, happiness, racial diversity, homeownership (a powerful measure of accumulated wealth), structural social capital, smoking, and unemployment - each of which are also important predic- 
tors of health and mortality in their own right — do not explain rising health disparities by educational attainment over time, either apart or together. ${ }^{[23,27,30,31]}$

Taken together, a subjective assessment of our findings thus suggests that the rise of mortality disparities in the United States over the past thirty years cannot simply be written off as a mechanical consequence of the changing sociodemographic or even cognitive characteristics of high school dropouts relative to high school graduates. Rather, it suggests that something else is at play.

Previous work exploring this question used more precise models applied to data with many fewer variables and a shorter follow up time. These analyses found that smoking and employment explained part of the difference. ${ }^{[32]}$ We opted not to repeat this approach in part because the structure of our data makes this less feasible and in part because a more subjective assessment of the trends in sociodemographic risks and survival time can provide a cleaner and clearer sense of the relationships between: (1) dropout status; (2) social, demographic, and cognitive risk factors; and (3) diverging survival times by dropout status. We ran our analyses many different ways - stratifying by gender, changing the age range of the participants included, and including/excluding various groups. We ultimately present the results combined because none of these analyses produced results that were substantively different from those we present as our base case analysis. The effect sizes were not much different when the sample was restricted to those 40 and over or when it was stratified by gender. By combining groups and including a broader age range, we are able to better statistically test the observed trends.

One downside to our approach is that it is possible that high school dropouts and graduates are diverging in large number of ways. Each of these could produce almost unnoticeable changes in survival time on their own, but collectively pro- duce a diverging survival time by dropout status. We do not know of a source of data as detailed or robust as the GSS-NDI that also allows for testing of joint effects (e.g., via seemingly unrelated regression). ${ }^{[33]}$ We must also acknowledge several other weaknesses of our analysis. By necessity, we limited the sample to individuals who responded to the survey, several variables were missing for a large part of the sample, and we were not able to study more-recent extracts of the GSS, since there would not be a sufficiently long follow-up period. However, non-response bias for any given year was minimal, and missing data was almost solely attributable to systematic exclusion of some variables form the GSS for a given year.

Whatever it is that underlies America's health woes, it is striking that a population health problem with little historical precedent has received so little attention from the media or from government funding agencies. To date, the only experimentally proven interventions that might improve population health in any form are parenting and early-education interventions, though some forms of social welfare also show limited promise. ${ }^{[26,34,35]}$ Such interventions appear to hold promise both in improving high school graduation rates and adult health, ${ }^{[35-37]}$ but whether they might address mortality disparities by educational attainment is an open question.

\section{ACKnOWledgements}

Peter Muennig conceived of the analysis and led manuscript development. Tal Gross conducted the statistical analyses and led conceptualization of the statistical approach given previous work in this area and contributed to manuscript development. Sherry Glied make significant contributions to the statistical approach and to the development of the manuscript.

\section{CONFlicts OF InTEREST Disclosure}

The authors declare that they have no competing interests.

\section{REFERENCES}

[1] Meara ER, Richards S, Cutler DM. The gap gets bigger: changes in mortality and life expectancy, by education, 1981-2000. Health Aff (Millwood). 2008; 27(2): 350-360. PMid: 18332489. http: //dx.doi.org/10.1377/hlthaff.27.2.350

[2] Ma J, Xu J, Anderson RN, et al. Widening educational disparities in premature death rates in twenty six states in the United States, 1993-2007. PLoS One. 2012; 7(7): e41560. PMid: 22911814. http://dx.doi.org/10.1371/journal.pone.0041560

[3] Olshansky SJ, Antonucci T, Berkman L, et al. Differences in life expectancy due to race and educational differences are widening, and many may not catch up. Health Aff (Millwood). 2012; 31(8): 1803 1813. PMid: 22869659. http://dx.doi.org/10.1377/hlthaff

\section{.2011 .0746}

[4] Murray CJL, Kulkarni SC, Michaud C, et al. Eight Americas: investigating mortality disparities across races, counties, and racecounties in the United States. PLoS Medicine. 2006; 3(9): e260. PMid: 16968116. http://dx.doi.org/10.1371/journal.pme d. 0030260

[5] Pappas G, Queen S, Hadden W, et al. The increasing disparity in mortality between socioeconomic groups in the United States, 1960 and 1986. N Engl J Med. 1993; 329(2): 103-109. PMid: 8510686 http://dx.doi.org/10.1056/NEJM199307083290207

[6] Jemal A, Ward E, Anderson RN, et al. Widening of socioeconomic inequalities in US death rates, 1993-2001. PLoS One. 2008; 3(5): e2181. PMid: 18478119. http://dx.doi.org/10.1371/journ 
al.pone. 0002181

[7] Singh GK, Siahpush M. Widening socioeconomic inequalities in US life expectancy, 1980-2000. International Journal of Epidemiology. 2006; 35(4): 969-979. PMid: 16684899. http://dx.doi.org/10. 1093/ije/dyl083

[8] Shkolnikov V, McKee M, Leon DA. Changes in life expectancy in Russia in the mid-1990s. The Lancet. 2001; 357(9260): 917-921. http://dx.doi.org/10.1016/S0140-6736(00)04212-4

[9] Oeppen J, Vaupel JW. Broken limits to life expectancy. Science. 2002; 296(5570): 1029. PMid: 12004104. http://dx.doi.org/10.11 26/science. 1069675

[10] Woolf SH, Aron L. US health in international perspective: Shorter lives, poorer health. Washington, DC: National Academies Press; 2013.

[11] Heckman JJ, LaFontaine PA. The American high school graduation rate: Trends and levels. The Review of Economics and Statistics. 2010; 92(2): 244-262. PMid: 20625528. http://dx.doi.org/10. 1162 /rest. 2010.12366

[12] Muennig P, Franks P, Jia H, et al. The income-associated burden of disease in the United States. Soc Sci Med. 2005; 61(9): 2018-2026. PMid: 15913866. http://dx.doi.org/10.1016/j.socscimed .2005 .04 .005

[13] Eggebeen DJ, Lichter DT. Race, family structure, and changing poverty among American children. American Sociological Review. 1991; 801-817. http://dx.doi.org/10.2307/2096257

[14] Gottfredson LS. Intelligence: is it the epidemiologists' elusive "fundamental cause" of social class inequalities in health? Journal of personality and social psychology. 2004; 86(1): 174-199. PMid: 14717635. http://dx.doi.org/10.1037/0022-3514.86.1.174

[15] Grossman M. Education and Nonmarket Outcomes. NBER working paper. 2005; 11582.

[16] Montez JK, Zajacova A. Explaining the widening education gap in mortality among U.S. white women. J Health Soc Behav. 2013; 54(2): 166-182. PMid: 23723344. http://dx.doi.org/10.1177 /0022146513481230

[17] Montez JK, Hayward MD. Early life conditions and later life mortality. In: International Handbook of Adult Mortality. edn.: Springer; 2011. 187-206p. http://dx.doi .org/10 .1007/978-90-481-9 996-9_9

[18] Montez JK, Zajacova A. Why have educational disparities in mortality increased among white women in the United States? Policy brief. J Health Soc Behav. 2013; 54(2): 165. http://dx.doi .org /10.1177/0022146513481230

[19] Montez JK, Berkman LF. Trends in the Educational Gradient of Mortality Among US Adults Aged 45 to 84 Years: Bringing Regional Context Into the Explanation. American journal of public health. 2014; 104(1): e82-e90. PMid: 24228659. http://dx.doi.org/1 $0.2105 /$ AJPH. 2013.301526

[20] Montez JK, Zajacova A. Why is life expectancy declining among low-educated women in the United States? Am J Public Health. 2014; 104(10): e5-7. PMid: 25122011. http://dx.doi.org/10.2105 /AJPH. 2014.302146

[21] Muennig P, Johnson G, Kim J, et al. The general social surveynational death index: an innovative new dataset for the social sciences. BMC Research Notes. 2011; 4: 385. PMid: 21978529. http://dx.doi.org/10.1186/1756-0500-4-385

[22] Laaksonen M, Martikainen P, Nihtilä E, et al. Home ownership and mortality: a register-based follow-up study of 300000 Finns. Journal of Epidemiology \& Community Health. 2008; 62(4): 293-297. PMid: 18339820. http://dx.doi.org/10.1136/jech. 2007.061309

[23] Chapman B, Fiscella K, Duberstein P, et al. Measurement confounding affects the extent to which verbal IQ explains social gradients in mortality. Journal of epidemiology and community health. 2014 PMid: 24729404. http://dx.doi.org/10.1136/jech-2013-2 03741

[24] Muennig P, Kuebler M, Kim J, et al. Gender differences in material, psychological, and social domains of the income gradient in mortality: implications for policy. PLoS One. 2013; 8(3): e59191. PMid: 23527129. http://dx.doi.org/10.1371/journal.pon e.0059191

[25] Kawachi I, Adler NE, Dow WH. Money, schooling, and health: Mechanisms and causal evidence. Ann N Y Acad Sci. 2010; 1186 56-68. PMid: 20201868. http://dx.doi.org/10.1111/j.174 9-6632.2009.05340.x

[26] Muennig P, Cohen AK, Palmer A, et al. The relationship between five different measures of structural social capital, medical examination outcomes, and mortality. Soc Sci Med. 2013; 85: 18-26. PMid: 23540361. http://dx.doi.org/10.1016/j.socscimed. 2013 02.007

[27] Wong MD, Shapiro MF, Boscardin WJ, et al. Contribution of major diseases to disparities in mortality. N Engl J Med. 2002; 347(20): 1585-1592. PMid: 12432046. http://dx.doi.org/10.1056/N EJMsa012979

[28] Muennig P, Fiscella K, Tancredi D, et al. The relative health burden of selected social and behavioral risk factors in the United States: implications for policy. Am J Public Health. 2010; 100(9): 1758-1764. PMid: 20019300. http://dx.doi.org/10.2105/AJPH. 2009.1 65019

[29] Batty GD, Deary IJ. Early life intelligence and adult health. BMJ. 2004; 329(7466): 585-586. PMid: 15361422. http://dx.doi.org /10.1136/bmj.329.7466.585

[30] Health UDo, Services H. The health consequences of smoking: a report of the Surgeon General. Atlanta, GA: US Department of Health and Human Services, Centers for Disease Control and Prevention, National Center for Chronic Disease Prevention and Health Promotion, Office on Smoking and Health. 2004; 62.

[31] Sorlie PD, Rogot E. Mortality by employment status in the National Longitudinal Mortality Study. Am J Epidemiol. 1990; 132(5): $983-$ 992. PMid: 2239913.

[32] Zellner A. An efficient method of estimating seemingly unrelated regressions and tests for aggregation bias. Journal of the American Statistical Association. 1962; 57(298): 348-368. http://dx.doi.o $\mathrm{rg} / 10.1080 / 01621459.1962 .10480664$

[33] Muennig P. Can universal pre-kindergarten programs improve population health and longevity? Mechanisms, evidence, and policy implications. Soc Sci Med. 2014

[34] Bilukha O, Hahn RA, Crosby A, et al. The effectiveness of early childhood home visitation in preventing violence: a systematic review. American journal of preventive medicine. 2005; 28(2): 11-39. PMid: 15698746. http://dx.doi.org/10.1016/j.amepre.20 04.10 .004

[35] Campbell F, Conti G, Heckman JJ, et al. Early childhood investments substantially boost adult health. Science. 2014; 343(6178): 1478 1485. PMid: 24675955. http://dx.doi.org/10.1126/science .1248429

[36] Muennig P, Schweinhart L, Montie J, et al. Effects of a prekindergarten educational intervention on adult health: 37-year follow-up results of a randomized controlled trial. Am J Public Health. 2009; 99(8): 1431-1437. PMid: 19542034. http://dx.doi.org/10.21 05/A JPH . 2008. 148353

[37] Muennig P, Robertson D, Johnson G, et al. The effect of an early education program on adult health: the Carolina Abecedarian Project randomized controlled trial. Am J Public Health. 2011; 101(3): 512 516. PMid: 21233425. http://dx.doi.org/10.2105/AJPH. 20 10.200063 